\title{
TATA KELOLA ADAPTIF WILAYAH PESISIR: META TEORI ANALISIS
}

\section{(ADAPTIVE GOVERNANCE OF COASTAL ZONE: META THEORY ANALYSIS)}

\author{
Lesmana Rian Andhika \\ Analis Kebijakan Pemerintah Kabupaten Aceh Tenggara; Email: lesmana.ra@outlook.co.id \\ Kantor Bupati Aceh Tenggara Jalan Iskandar Muda No. 4 Kutacane - Aceh Tenggara 24651 \\ Dikirim 10 Januari 2021, Direvisi 12 Maret 2021, Disetujui 29 Maret 2021
}

\begin{abstract}
Abstrak: Tata kelola adaptif melibatkan dan mengarahkan kinerja ke arah pencapaian hasil dalam lingkungan yang semakin kompetitif. Zona pesisir dan sumber daya alam penting untuk dikelola, menawarkan peluang dan tantangan untuk meningkatkan pembangunan ekonomi, sosial budaya secara berkelanjutan. Tujuan dari penelitian ini ingin menelusuri berbagai kasus yang terkait dengan pengelolaan wilayah pesisir. Secara spesifik kepada adaptive governance yang telah berkembang sebagai pendekatan analitis untuk memahami tata kelola sumber daya alam yang mengambil landasan nya dari ketergantungan sistem sosial dan ekologi. Meta Theory digunakan untuk memberikan argumentasi terhadap dimensi adaptive governance. Beberapa kasus dipilih secara sengaja untuk memperkuat argumentasi penelitian. Dengan demikian penggunaan adaptive governance dalam tata kelola wilayah pesisir dapat memberikan peluang kepada masyarakat untuk aktif mengelola berbagai isu wilayah pesisir. Oleh sebab itu penelitian ini memberikan informasi bahwa tren untuk meningkatan keterlibatan masyarakat menjadi lebih besar. Tata kelola wilayah pesisir menyediakan pertumbuhan ekonomi baru bagi masyarakat lokal. Kearifan lokal berperan penting untuk menjadi stabilitas moderinasi yang dibawa dalam tata kelola adaptif itu sendiri.
\end{abstract}

Kata kunci: Adaptif, Tata kelola, Wilayah Pesisir

\begin{abstract}
Adaptive governance involves and directs performance towards achieving results in an increasingly competitive environment. Coastal zones and natural resources are important to be managed, offering opportunities and challenges to enhance sustainable economic, socio-cultural development. The purpose of this study is to explore various cases related to the management of coastal areas. Specifically, to adaptive governance that has developed as an analytical approach to understanding natural resource that takes its foundation from social and ecological system dependence. Meta Theory is used to provide arguments for the dimensions of adaptive governance. Several cases were chosen deliberately to strengthen the research argumentation. Thus, the use of adaptive governance in coastal zone provides opportunities for community to manage various coastal area issues. Therefore, this study provides information that the trend to increase community involvement is greater. Adaptive governance of coastal zone provides new economic growth for local communities. Local wisdom plays an important role in bringing the stability of moderation brought about in adaptive governance itself.
\end{abstract}

Keywords: Adaptif, Governance, Coastal Zone

\section{PENDAHULUAN}

Menjadi Negara Kepulauan terbesar di dunia, Indonesia diberkahi dengan sumber daya pesisir dan laut yang berlimpah dan beragam. Zona pesisir dan sumber daya alam dibangun dan dikelola untuk menawarkan peluang dan tantangan untuk meningkatkan pembangunan ekonomi, sosial budaya secara berkelanjutan. Lebih lanjut, pergeseran pusat ekonomi global dari Atlantik ke Lingkar Pasifik akan meningkatkan penggunaan wilayah laut dan pesisir Indonesia untuk berbagai kegiatan pembangunan, terutama komunikasi dan transportasi laut, perikanan dan akuakultur, pariwisata, pertambangan dan energi, industri maritim, dan rekayasa pesisir dan lepas pantai. Tidak hanya keberhasilan ekonomi dari tata kelola wilayah pesisir tetapi juga menyebabkan degradasi lingkungan pada tingkat yang mengancam kapasitas berkelanjutan ekosistem laut dan pesisir.

Namun sampai saat ini permasalahan pengelolaan wilayah pesisir masih terus 
terjadi, seperti privatisasi oleh perusahaan tertentu, tumpang tindih peraturan pemerintah daerah, deskriminasi masyarakat lokal, dan faktor lingkungan seperti abrasi. Beberapa data dapat ditelusuri seperti kasus yang terjadi pada Kabupaten Bintan Provinsi Kepulauan Riau dimana terdapat 14 perusahan dari 117 jumlah perusahan asing yang menguasai lahan pariwisata beserta objek wisata (pantai, hutan dan laut) dengan luas penguasaan lahan cukup signifikan yaitu sekitar 4.882,4 hektar (DPMPTSPTK Kab.Bintan Tahun 2018).

Di sisi yang lain Pemerintah Pusat terus mendorong Pemerintah Provinsi untuk segera menyelesaikan pembuatan peraturan daerah rencana zonasi wilayah pesisir dan pulau-pulau kecil (RZWP3K). Dari 34 provinsi, saat ini baru 17 provinsi yang sudah menetapkan Perda RZWP3K dan menjadikan acuan dalam rencana pembangunan di wilayahnya masingmasing. Ke-17 provinsi yang sudah mempunyai Perda RZWP3K, adalah Sulawesi Utara, Sulawesi Barat, Sulawesi Tengah, Gorontalo, Nusa Tenggara Barat, Nusa Tenggara Timur, Lampung, Sumatera Barat, Jawa Timur, Jawa Tengah, Daerah Istimewa Yogyakarta, Kalimantan Selatan, Kalimantan Barat, Kalimantan Tengah, Kalimantan Utara, Maluku, dan Maluku Utara (Ambari, 2019).

Artinya bahwa Undang-Undang Republik Indonesia Nomor 1 Tahun 2014 tentang Perubahan Atas Undang-Undang Nomor 27 Tahun 2007 tentang Pengelolaan Wilayah Pesisir dan Pulau-Pulau Kecil pada pasal 1 angka 1 menegaskan "Pengelolaan Wilayah Pesisir dan PulauPulau Kecil adalah suatu pengoordinasian perencanaan, pemanfaatan, pengawasan, dan pengendalian sumber daya pesisir dan pulau-pulau kecil yang dilakukan oleh Pemerintah dan Pemerintah Daerah, antar sektor, antara ekosistem darat dan laut, serta antara ilmu pengetahuan dan manajemen untuk meningkatkan kesejahteraan rakyat". Salah satu poin utama dalam pasal tersebut adalah pengelolaan wilayah pesisir dilakukan untuk meningkatkan kesejahteraan rakyat.

Para praktisi dan akademisi memberikan argumentasi tentang tata kelola yang baik. Praktik nya kompleksitas, intensitas internal dan eksternal menjadi unsur utama agar tetap fokus pada arahan, tindakan dengan tujuan. Untuk itu diperlukan terobosan yang koheren antara beberapa konseptualisasi dan praktek untuk menciptakan tata kelola (Bevir, 2012; Assche, Beunen, \& Duineveld, 2014). Tujuan dari tata kelola setidaknya berinteraksi secara dinamis satu sama lain dan semua nya membentuk kesatuan yang unik dengan membangun inklusifitas relasi politik antara negara/pemerintah, civil society, dan sektor bisnis. Sedangkan karakteristik dari proses tersebut berkontribusi pada peningkatan kapasitas, inovasi, kreativitas dan respon adaptif (Andhika, 2017).

Selanjutnya, beberapa studi menjadi informasi penting untuk meninjau sejauhmana pengelolaan wilayah pesisir. Schmidt, et al (2013) dalam studi nya menemukan untuk mengatasi permasalahan wilayah pesisir (banjir dan erosi) cara alternatif yang digunakan terletak pada proses tata kelola adaptif, yang melibatkan kepercayaan dan partisipasi penuh dari masyarakat setempat. Namun kurang nya kejelasan kebijakan dan kemauan politik, ilmu yang lemah dan miskin koordinasi dari pemangku kepentingan, membuat pendekatan adaptif terorganisir sangat bermasalah. Nurhidayah (2011) menemukan kerusakan terumbu karang, mangrove serta overfishing adalah salah satu indikator ada nya permasalahan dalam manajemen sumber daya laut. Untuk itu pendekatan pesisir terpadu menjadi solusi untuk menggantikan pendekatan sektoral, dalam praktik nya tidak mampu mengatasi permasalahan kompleks manajemen sumber daya pesisir dan laut.

Studi-studi di atas memberikan argumentasi bahwa pengelolaan wilayah pesisir menyisakan berbagai masalah pengelolaannya, hal ini yang menjadi fokus 
praktisi dan akademisi untuk menawarkan solusi baru dalam pengelolaan wilayah pesisir. Kompleksitas maupun konflik tidak dapat dihindari, dan tata kelola adaptif sebagai citra pengambilan keputusan yang seimbang sebagai cara yang produktif. Integrasi kebijakan akan menjadi lebih sulit dan lebih penting dalam tata kelola wilayah pesisir, karena hal ini adalah arena di mana efek dari banyak kegiatan yang melibatkan berbagai kelompok, kepentingan, dan sosial budaya semakin terlihat. Namun terdapat pertanyaan apakah dalam praktik nya dengan wilayah yang berbeda termasuk kearipan lokal, solusi baru yang ditawarkan dapat menunjukkan hasil yang lebih besar. Untuk itu tujuan dari penelitian ini ingin menelusuri berbagai kasus yang terkait dengan pengelolaan wilayah pesisir. Secara spesifik kepada adaptive governance yang telah berkembang sebagai pendekatan analitis untuk memahami tata kelola sumber daya alam yang mengambil landasan dari ketergantungan sistem sosial dan ekologi. Artikel penelitian ini menelusuri hal tersebut menggunakan pendekatan meta theory analysis yang jarang dilakukan, dan pada umum nya studi yang dipublikasikan dengan pendekatan deskriptif, dan lebih dominan menggunakan analisis literature review.

Tata kelola adaptif telah muncul dalam dekade terakhir sebagai jalan yang menarik dari teori dan praktek untuk manajemen holistik masalah lingkungan yang kompleks (Bevir, 2012; Schmidt, et al 2013; Sharma-Wallace, Velarde, \& Wreford, 2018). Tanpa mengabaikan tradisi, pendekatan baru perlu dianut yang mengakui bahwa berbagai program pemerintah semakin diperebutkan. Proposisi ini dapat bermanfaat dan dikelompokkan dalam kerangka kerja konseptual pengelolaan adaptif (Lee \& Petts, 2013; Sharma-Wallace, Velarde, \& Wreford, 2018). Tata kelola adaptif melibatkan dan mengarahkan kinerja ke arah pencapaian hasil dalam lingkungan yang semakin kompetitif. Pemantauan masih akan diperlukan untuk memastikan tidak hanya hasil sedang dicapai, tetapi bahwa proses yang diupayakan memiliki integritas dan akuntabilitas yang dituntut oleh publik.

Kemudian beberapa orientasi data tata kelola adaptif yang teridentifikasi dari beberapa tulisan di ilustrasikan pada Tabel di bawah ini.

Tabel 1. Orientasi Konsep Tata Kelola Adaptif

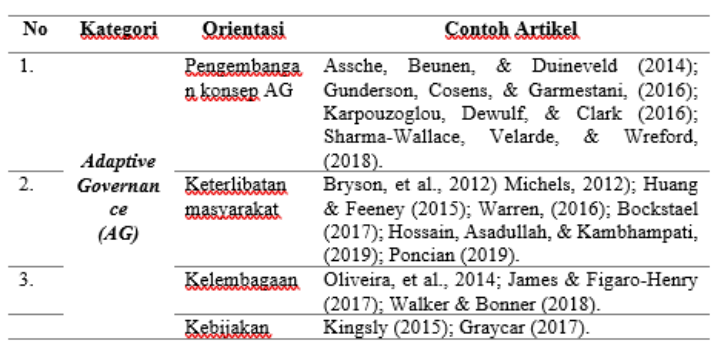

Sumber: Data Sekunder (2019)

Tata kelola adaptif menuntut fleksibilitas organisasi yang lebih besar, menuntut lebih banyak kemauan untuk bereksperimen mulai dari yang kecil, menguji apa yang berhasil dan gagal dengan cepat. Hal ini dapat dilakukan oleh kepemimpinan fasilitatif, dimana kemitraan kolaboratif dibentuk dengan orang lain untuk memberikan hasil yang lebih baik. Dibutuhkan ketangkasan yang jauh lebih besar dari pada yang diizinkan oleh struktur organisasi tradisional, dan menuntut pemerintah agar dapat lebih baik terlibat dengan masyarakat. Dalam beberapa kasus tata kelola wilayah pesisir, tata kelola adaptif tegas menolak fokus sempit pada manajemen linear untuk hasil yang lebih baik dengan mencapai keberlanjutan ekologis dan membangun kapasitas masyarakat dalam kondisi ketidakpastian (Karpouzoglou, Dewulf, \& Clark, 2016; Sharma-Wallace, Velarde, \& Wreford, 2018). Juga tata Kelola mengacu pada pengaturan kelembagaan yang membentuk keputusan aktor dan perilaku kebijakan, termasuk pelaksanaan kewenangan dalam kelompok atau organisasi. 
Agar adaptif, tata kelola harus mencakup gambaran besar, tidak hanya secara geografis, tetapi juga secara kelembagaan termasuk semua lembaga formal dan informal (Chaffin, Gosnell, \& Cosens, 2014). Gambaran besar ini harus mencakup beberapa level kerangka kerja pemerintah baik jangka pendek dan jangka panjang, tetapi juga transisi antara negara, sosial yang berbeda, memungkinkan untuk transformasi. Yang paling penting untuk transformasi adalah pembelajaran sosial, yang berarti orang harus dilibatkan. Dalam kasus wilayah pesisir pengelolaan adaptif merupakan proses yang berkesinambungan. Hal ini terjadi karena beberapa faktor seperti, masalah lingkungan, geopolitik, sosial, budaya, dan ekonomi. Model adaptif memiliki potensi untuk menyebabkan cara yang lebih demokratis termasuk perencanaan dengan cara politik yang lebih elegan dari penggabungan kelompok kepentingan. Dengan didukung oleh kemauan politik yang handal dan terkoordinasi dengan otoritas kelembagaan responsif untuk membangun kepercayaan, partisipasi yang efektif dan keadilan sosial antara para pemangku kepentingan sebagai bahan yang paling penting untuk mengatasi masalah dengan kejelasan kebijakan (Schmidt, Prista, Suraiva, O'Riodan, \& Gomes, 2013).

Lebih lanjut pengelolaan adaptif mengaanalisis berbagai aspek yang membangun tata kelola multi level dan bagaimana semua aspek membantu membangun ketahanan terhadap perubahan global. Untuk itu para sarjana menekankan perlunya bentuk tata kelola yang fleksibel, terintegrasi, dan holistik yang dapat menangani kompleksitas sosial ekonomi (Sharma-Wallace, Velarde, \& Wreford, 2018). Tata kelola adaptif menyiratkan lebih dari partisipasi pemangku kepentingan dan perencanaan terpadu dengan mengabungkan berbagai jalan analisis seperti manajemen adaptif, pengelolaan bersama adaptif, pengelolaan ekosistim, dan berbagai bentuk pengelolaan sumber daya yang terintegrasi formal dan informal. Dalam konteks wilayah pesisir, pengelolaan adaptif mesti dilakukan dengan adopsi disiplin ilmu yang berkaitan secara menyeluruh untuk mendapatkan hasil analisis yang lebih baik.

\section{METODOLOGI}

Argumentation theory method (metareasoning atau meta-argumentation) digunakan dalam artikel penelitian ini. Bertujuan untuk interpretasi beralasan dan/atau evaluasi argumen terhadap teori terkait. Penelitian ini juga dibangun sebagai penelitian pendahuluan (preliminary research) yang berasal dari beberapa konsep teoritis yang ada dan relevan untuk mengambarkan mekanisme, masalah tata kelola adaptif. Teori/konsep tersebut perlu diberikan argumentasi sebagai upaya mengungkapkan tentang satu argumen atau lebih argumen, dapat dikontraskan dengan argumentasi lain nya. Biasa nya terkait dengan hal seperti fenomena alam, sejarah, politik, kebijakan, tindakan manusia, dan sebagainya sebagai satu set pernyataan yang mencoba untuk membenarkan klaim mendukung dengan alasan mempertahankannya dari keberatan, atau keduanya (Finocchiaro, 2013). Komponen yang disertakan dalam membangun argumentasi tergantung kepada tujuan penelitian, peneliti mengkombinasikan beberapa gagasan yang ada, dan pengamatan dunia empiris yang berhubungan dengan tema penelitian. Dalam penelitian ini dipertimbangkan menggunakan gambar, tabel untuk menunjukkan realitas alasan yang dapat disimpulkan. Finocchiaro (2013) memberikan cara membangun metode argumentasi teori dengan memahami dari perumusan, pengujian, sistematik, klarifikasi, dan penerapan konsep dan prinsip untuk interpretasi, evaluasi, dan praktik penalaran dan argumentasi. 


\section{HASIL DAN PEMBAHASAN}

Oleh sebab itu beberapa kasus yang dipublikasikan menempatkan tata kelola adaptif menarik banyak ide-ide dari analisis sistem, ekologi, ekonomi politik, sumber daya dan ekonomi lingkungan, ekonomi perilaku, dan ilmu sistem yang kompleks (Karpouzoglou, Dewulf, \& Clark, 2016). Namun dalam pengunaannya terdapat dimensi untuk memahami tata kelola adaptif adalah collaboration, coordination, building social capital; community empowerment and engagement; capacity development; knowledge and decisionmaking, leadership capacity (SharmaWallace, Velarde, \& Wreford, 2018).

\section{Analisis Meta Teori Adaptive Governance Wilayah Pesisir}

\section{Collaboration}

Kolaborasi merupakan proses interaksi orang atau organisasi yang bekerjasama untuk menyelesaikan tugas atau mencapai tujuan. Untuk itu dalam tata kelola wilayah pesisir diperlukan kolaborasi berbagai pihak, seperti terbit nya beberapa pengaturan pengelolaan wilayah pesisir sebagai tanggapan terhadap berbagai kondisi perubahan sosial dan ekologis. Dalam hal ini peran pemerintah menjadi dominan sebagai katalisator, seperti koordinasi berbagai sektor kebijakan, aktor-aktor non-negara serta integrasi pengetahuan ilmiah dan keahlian dari berbagai disiplin ilmu. Namun studi baru-baru ini menyoroti kolaborasi tersebut dimungkinkan lebih menyerukan perhatian yang lebih besar pada bentuk-bentuk pengetahuan lokal dan awam serta nilainilai budaya yang dipegang oleh masyarakat pesisir (Walsh, 2019). Berbagai kondisi mungkin saja terjadi, ketidaknetralan pemerintah dengan memberikan berbagai kemudahan pada sektor swasta tanpa memperhatikan masyarakat menjadi masalah tersendiri. Dengan alasan investasi, pada umum nya sektor swasta akan memberikan tekanan kepada pemerintah dengan bentuk kebijakan (Ojwang, et al., 2017; Fan, et al., 2018). Walaupun pada prinsip nya pemerintah tidak dapat diintervensi namun oknum pejabat negara sering melakukan tindakan yang bertentangan dengan aturan yang berlaku (Kingsly, 2015; Graycar, 2017).

Sebagai contoh, organisasi cenderung bekerja sama dalam program multisektor hanya ketika mereka diberikan kontrol penuh atas pengelolaan komponen mereka sendiri. Segala pengaturan yang kurang dari itu tidak akan menghasilkan hasil yang diinginkan. Pendekatan terpadu perlu diformalkan dengan cara yang memungkinkan setiap lembaga untuk mempertahankan status independen nya. Sementara pada saat yang sama memungkinkannya untuk melakukan kegiatan dalam kerangka kerja yang disepakati bersama. Model ini berisi unsurunsur desain kelembagaan untuk melaksanakan program pengelolaan zona pesisir terpadu. Ada tingkat sentralitas dan ikatan timbal balik yang lebih tinggi, memiliki homogenitas aktor yang lebih besar dengan satu aktor yang tersentralisasi. Masyarakat sipil memainkan peran yang lebih besar dan organisasi pemerintah memainkan peran yang lebih sentral. Perbedaan antara kedua peran tersebut mempertanyakan penggunaan strategi dan menyarankan model tata kelola dan hubungan yang ada dalam konteks lokal (Ernoul \& Wardell-Johnson, 2013; James \& Figaro-Henry, 2017).

Untuk itu upaya kolaboratif dapat dimulai melalui pengaturan formal atau melalui interaksi informal yang berkembang dalam pekerjaan bersama, bagaimanapun keberhasilan kolaborasi membutuhkan peserta untuk memberikan perhatian untuk masalah proses. Keuntungan kolaboratif yang berkaitan dengan potensi sinergi dari bekerja secara kolaboratif, tetapi kolaboratif yang berkaitan dengan hasil seringkali mengecewakan dalam kenyataan. Kompleksitas yang mendasari situasi 
kolaboratif disampaikan dengan cara yang tampak nyata bagi mereka yang terlibat. Ini bertujuan untuk memberdayakan mereka yang terlibat melalui melegitimasi yang dialami dan memberikan pegangan konseptual untuk membantu mengatasi masalah-masalah praktis yang terlibat (Williams, 2016; Ahlhorn, 2018). Studi baru-baru ini juga menyoroti pentingnya pendekatan kolaboratif kolaboratif untuk mengakui peran masyarakat lokal dalam pengelolaan wilayah pesisir dengan strategi manajemen terpadu yang sama dan menyarankan perlunya mengakui pentingnya model tata kelola dan hubungan yang ada dalam konteks lokal (Fadli \& Nurlukman, 2018).

\section{Coordination}

Taktik umum dalam banyak program pengembangan wilayah pesisir adalah untuk mengkoordinasikan pemangku kepentingan ketika ada komunikasi yang buruk antara pemerintah, swasta, dan masyarakat lokal, atau ketika solusi untuk suatu masalah mengharuskan pemangku kepentingan untuk bekerja sama. Pengkoordinasian pemangku kepentingan dapat terjadi dari lokakarya, hingga proses mediasi formal. Proses yang mengharuskan lembaga pemerintah untuk menyelesaikan konflik kebijakan dengan rencana, kebijakan, program negara dan daerah untuk tujuan mencapai konsistensi. Meskipun koordinasi telah menjadi masalah dalam pemerintahan selama berabad-abad, dan menjadi perhatian khusus pada tahun 1980-an, dan tetap menjadi perhatian utama sampai saat ini. Koordinasi sebagian merupakan fungsi dari keberhasilan "New Public Management" dan penekanannya pada pengelolaan program individu. Untuk itu koordinasi menjadi alat untuk menghubungkan berbagai kepentingan dari berbagai unsur yang terkait. Koordinasi juga dapat digunakan sebagai alat kontrol dari setiap kegiatan, isu-isu terkini yang berhubungan dengan objek permasalahan (Peters, 2018).
Meskipun koordinasi positif dapat menjadi kontribusi besar bagi administrasi dan kebijakan, namun koordinasi strategis akan melibatkan koordinasi program dan sasaran strategis pemerintah yang luas. Untuk koordinasi strategis, tindakan akan diperlukan secara prospektif dari pada retrospektif seperti yang sering terjadi untuk bentuk koordinasi lainnya (Peters, 2018; Trein, Meyer, \& Maggetti, 2019). Sebagai contoh, faktor lain yang memberi tekanan pada peningkatan koordinasi adalah munculnya masalah-masalah sulit yang tidak dapat dengan mudah diselesaikan melalui tindakan setiap kelompok kepentingan yang terlibat. Masalah-masalah ini, kadang-kadang ditandai dengan sebagai masalah besar, membutuhkan upaya koordinasi yang jauh lebih besar daripada melakukan penyelesaian masalah yang relatif kecil yang masuk ke dalam domain organisasi pemerintah. Upaya untuk menghadapi masalah seperti perubahan iklim atau pembangunan berkelanjutan pengelolaan wilayah pesisir membutuhkan keterlibatan banyak pemerintah, dan karenanya koordinasi sangat dibutuhkan. Dengan adanya otonomi daerah pengelolaan wilayah pesisir menekankan koordinasi horizontal, tetapi dalam semua sistem politik, beberapa koordinasi vertikal juga penting. Ini terutama penting dalam era otonomi daerah di mana pemerintah daerah mungkin memiliki otonomi yang substansial. Oleh karena itu, pemerintah pusat mungkin perlu menemukan beberapa cara untuk mengarahkan sistem koordinasi secara keseluruhan.

\section{Building social capital}

Asumsi-asumsi dari tesis modal sosial, bahwa nilai-nilai bersama dan ikatan asosiasi yang kuat berkontribusi pada tata pemerintahan yang baik. Modal sosial merupakan komponen budaya masyarakat modern, membangun modal sosial biasanya dipandang sebagai tugas untuk reformasi ekonomi. Tetapi tidak seperti kebijakan dan institusi ekonomi, modal sosial tidak 
diciptakan atau dibentuk oleh kebijakan publik tetapi diwariskan oleh komunitas lokal (Henocque, 2013). Karena itu meningkatkan modal sosial adalah tentang memromosikan pengetahuan lokal yang berakar dalam praktik masyarakat lokal. Dalam mencari kondisi modal sosial 'ikatan' horizontal dalam masyarakat yang dapat berkontribusi secara konstruktif terhadap tindakan kolektif pada pengelolaan sumber daya alam. Pendekatan-pendekatan ini telah dikritik karena kecenderungan untuk mengabaikan kompleksitas struktural internal masyarakat, khususnya berbagai kepentingan aktor lokal dan khususnya para elit yang berada dalam posisi untuk mengambil manfaat dari akses sumber daya yang tersedia (Warren, 2016).

Modal sosial dapat dibangun dari berbagai cara seperti partisipasi publik (Mergel, 2013; Warren, 2016), skenario perencanaan (Lang \& Ramírez, 2017), pengunaan media sosial (Kahaia \& Lei, 2019). Sebagai contoh, studi yang dilakukan Warren (2016) di Bali menemukan kekuatan hukum adat Bali dan tingginya tingkat partisipasi yang diperlukan dalam ranah sosial-ritual. Oleh sebab itu apresiasi yang lebih kompleks dari hubungan vertikal (otoritas) dan horizontal (solidaritas) antara para pemimpin dan penduduk desa sangat diperlukan, dan bahwa pendekatan kelembagaan dan skenario eksplorasi yang lebih bernuansa dapat menganalisis aturan yang berkembang akan meningkatkan intervensi kebijakan terkait. Di sisi yang lain media tradisional juga mempromosikan ikatan modal sosial, namun jika media tradisional mempromosikan modal sosial hanya untuk mereka yang memiliki self-efficacy sosial yang tinggi, ini dapat membahayakan untuk menjembatani modal sosial bagi pengguna dengan self-efficacy diri sosial yang rendah. Sama seperti hal nya para praktisi telah mengamati bahwa perencanaan skenario berkontribusi untuk membangun modal sosial baru. Dalam istilah perencanaan skenario, modal sosial baru dapat menyediakan akses ke informasi baru, opsi strategis baru dan peluang kolaboratif yang belum pernah terjadi sebelumnya. (Lang \& Ramírez, 2017).

Dari beberapa kasus di atas memberikan informasi untuk membangun komunitas pesisir yang kuat, ketahanan adalah kemampuan untuk bangkit kembali setelah terjadi persoalan antara masyarakatmasyarakat, masyarakat-pemerintah, dan masyarakat-sektor swasta. Ketika kita memikirkan ketahanan, kita cenderung menyamakannya dengan ketahanan ekologis, tetapi ini juga mencakup ketahanan sosial. Peningkatan modal sosial melalui pembangunan jaringan di komunitas menghasilkan komunitas yang lebih kuat melalui program yang membangun jejaring sosial dan ikatan dengan masyarakat. Modal sosial juga didefinisikan sebagai jejaring sosial yang memiliki kepercayaan dasar dan dibangun atas dasar timbal balik. Oleh sebab itu Warren (2016) mengingatkan bahwa modal sosial dan kerumitan negosiasi tindakan kolektif pada masalah lingkungan di mana kepentingan yang saling bertentangan dan ikatan sosial yang padat membuat tindakan lokal menjadi sulit.

\section{Community empowerment and engagement} Pemberdayaan menyangkut hubungan kekuasaan dan strategi intervensi yang pada akhirnya bertujuan untuk menantang ketidakadilan sosial melalui proses politik dan sosial. Pemberdayaan bertujuan untuk memungkinkan orang mengambil kendali tindakan dan keputusan yang memengaruhi kehidupan mereka. Pemberdayaan masyarakat mengacu pada proses memungkinkan masyarakat untuk meningkatkan kontrol atas kehidupan mereka. Oleh karena itu, pemberdayaan masyarakat lebih dari sekadar keterlibatan, partisipasi, atau keterlibatan masyarakat. 
Hal ini menyiratkan kepemilikan dan tindakan masyarakat yang secara eksplisit bertujuan untuk perubahan sosial dan politik. Di mana masyarakat diberdayakan untuk melihat berbagai manfaat, partisipasi demokratis lokal didorong, peningkatan kepercayaan diri dan keterampilan di antara penduduk setempat.

Keterlibatan dan partisipasi masyarakat mengarah pada pemberian layanan berkualitas, lebih responsif, dan hasil yang lebih baik bagi masyarakat. Selain itu model pelatihan, bantuan teknis, pendidikan, dan berbagi informasi yang bermanfaat bagi seluruh masyarakat difokuskan pada pemberdayaan orang melalui advokasi diri. Keterlibatan masyarakat terjadi untuk memberikan umpan balik kebijakan dan evaluasi sistem, dengan menggunakan kerangka sosialekologis yang mendorong keterlibatan masyarakat di tingkat individu, interpersonal, organisasi, komunitas, sistem, dan kebijakan

Sebagai contoh, komitmen kebijakan dengan komunitas proaktif yang mendorong keterlibatan dalam pengambilan keputusan dan proses tata kelola (Bryson, et al., 2012; Huang \& Feeney, 2015). Bagaimana pemerintah menanggapi upaya masyarakat untuk keterlibatan dalam proses pengambilan keputusan (Michels, 2012). Khusus nya, apakah komitmen pemerintah terhadap keterlibatan masyarakat diterjemahkan menjadi respon positif terhadap upaya partisipasi dari bawah ke atas oleh komunitas terkait. Dengan anggota masyarakat, politisi dan pejabat pemerintah lokal, dan pusat, membuat analisis kritis kerangka kerja kebijakan tata kelola wilayah pesisir. Untuk hal ini pada umum nya respon negatif terhadap upaya masyarakat menuntut pemeriksaan yang lebih mendalam tentang politik sumber daya ekstraktif relatif terhadap praktik pelibatan masyarakat (Poncian, 2019). Selain itu hubungan positif antara pemberdayaan akan mengakibatkan kepuasan hidup. Dijelaskan oleh fakta bahwa pria dan wanita berbeda dalam cara mereka mendapatkan kepuasan dari berbagai bidang pemberdayaan. (Hossain, Asadullah, \& Kambhampati, 2019)

\section{Capacity development}

Pengembangan kapasitas adalah di proses melalui individu, organisasi dan masyarakat untuk memperoleh, memperkuat dan mempertahankan kemampuan serta menetapkan dan mencapai tujuan pembangunan mereka sendiri dalam waktu tertentu. Pengembangan wilayah pesisir mempromosikan praktik kebijakan, wawasan, dan perilaku, atau cara untuk menghasilkan tujuan yang bermanfaat dan memberdayakan masyarakat. Pengembangan termasuk solusi dan memiliki potensi untuk mengatasi masalah yang substansial wilayah pesisir. Untuk itu tindakan berani dan transformatif oleh semua pemangku kepentingan diperlukan dengan melanjutkan ke arah praktik dengan merencanakan solusi baru yang lebih efisien. Solusi yang dicoba dan benar perlu disesuaikan, ditingkatkan dengan ekplorasi pendekatan baru untuk memajukan kapasitas pengembangan. Pengembangan tersebut perlu menciptakan peluang inklusif bagi pemerintah, sektor swasta dan masyarakat.

Pengembangan kapasitas juga berhubungan dengan asal usul kolonisasi atau yang belum didekolonisasi. Asumsi yang mendasari sebagian besar adalah bahwa ada kekurangan dalam kemampuan kelompok yang bersangkutan, dan tidak mempertanyakan kemungkinan bahwa sistem atau struktur mungkin tidak berfungsi. Desain dan implementasi yang berkelanjutan dari sistem manajemen tata kelola wilayah pesisir secara umum terus didasarkan pada asumsi mendasar dari kurang nya kapasitas masyarakat untuk tata kelola sumber daya. Meskipun pelaksanaan serangkaian pendidikan dan pelatihan bukan pendekatan baru untuk pengembangan kapasitas, komitmen untuk pedagogi kritis. Penjelasan pengembangan 
kapasitas tentang apa dan untuk siapa berdasarkan asumsi kapasitas akan menentukan kapasitas, dan tujuannya, pada umum nya dibimbing oleh teori. Tujuan pengembangan kapasitas untuk mengembangkan keterampilan sehingga orang dapat masuk ke dalam struktur yang tidak adil atau untuk kemudahan kontrol sosial dengan mendukung peningkatan keterampilan dan pengetahuan untuk dapat menghadapi keadaan yang terus berubah. Agar masyarakat lokal menjadi mitra yang bersedia dalam sistem tata kelola yang cacat, banyak pekerjaan yang diperlukan untuk terus mengatasi kelemahan dan kegagalan, dan secara kritis menantang status quo (Bockstael, 2017).

Fakta nya, masalah pengembangan kapasitas sebagian besar telah ditanggapi dari sudut pandang teknis, sedangkan aspek pengembangan kapasitas kelembagaan dan administrasi tampak nya kurang terwakili. Namun secara umum pengembangan kapasitas meliputi pengembangan sumber daya manusia, proses melengkapi individu dengan pemahaman, keterampilan dan akses informasi, pengetahuan dan pelatihan yang memungkinkan mereka untuk bekerja secara efektif. Pengembangan organisasi, penjabaran struktur manajemen, proses dan prosedur, tidak hanya di dalam organisasi tetapi juga pengelolaan hubungan antara berbagai organisasi dan sektor (publik, swasta dan masyarakat). Pengembangan kerangka kerja kelembagaan dan hukum, membuat perubahan hukum dan peraturan, memungkinkan organisasi, lembaga di semua tingkatan dapat meningkatkan kapasitas mereka.

\section{Knowledge and decision-making}

Dari proses politik akan dilakukan pengambilan keputusan sebuah kebijakan, oleh sebab itu untuk menghasilkan berbagai keputusan (kebijakan, kesepakatan, perjanjian) para pemangku kepentingan akan mengunakan argumentasi dalam menanggapi berbagai isu yang terkait dengan kepentingan masing-masing. Sebagian besar organisasi memiliki sistem pengambilan keputusan yang tersentralisasi. Penciptaan makna struktur kolektif, berdasarkan pada informasi yang dapat diandalkan pada semua tingkat pengambilan keputusan, membuka jalan menuju desentralisasi pengambilan keputusan yang terlibat dengan struktur koordinasi antar organisasi. Singkat nya, koordinasi yang lebih efisien dan andal antara organisasi bergantung pada peningkatan sistem pengambilan keputusan dalam setiap organisasi.

Tetapi ketika orang merasa strategi proses pengambilan keputusan adil, mereka menunjukkan tingkat kerja sama sukarela yang tinggi berdasarkan pada sikap kepercayaan dan komitmen. Sebaliknya, ketika orang merasa bahwa proses nya tidak adil, mereka menolak untuk bekerja sama dengan menimbun ide dalam menyusun dan melaksanakan keputusan strategis. Pengetahuan dapat berperan mengevaluasi informasi dan penting nya kriteria keputusan, menyusun ukuran yang menunjukkan apakah keputusan didasarkan pada pengetahuan yang tersedia dan kriteria apa yang sebenarnya dipertimbangkan. (Oliveira, Rozenfeld, Phaal, \& Probert, 2014). Oleh sebab itu sifat dari strategi transfer pengetahuan yang berbeda berdampak pada proses dan hasil penyelesaian masalah dengan memeriksa manipulasi, atau kendala, pendekatan pemecahan masalah untuk transfer pengetahuan (Walker \& Bonner, 2018).

Lebih lanjut untuk menghindari situasi yang tidak diinginkan, hubungan antara dunia pengetahuan dan dunia pengambilan keputusan harus dibangun secara hati-hati, dengan menghubungkan proses pengambilan keputusan dengan penelitian akademik dan mengembangkan tujuan penelitian dalam menanggapi tuntutan pembuat keputusan. Dengan membuat koneksi ini secara bertahap, pengetahuan dapat menghasilkan wawasan dan pandangan baru bagi para pembuat keputusan dan pemangku kepentingan yang terlibat, sehingga mengubah persepsi dan definisi masalah. Dengan cara ini, para 
aktor ini belajar tentang kemungkinan dari beberapa alternatif serta persepsi masingmasing, dan dengan demikian dapat membuat keputusan tepat yang mengarah ke solusi yang paling diinginkan dan diterima secara sosial.

\section{Leadership capacity}

Membangun kapasitas kepemimpinan biasa nya melibatkan pembentukan model kompetensi untuk menggambarkan keterampilan dan perilaku yang diperlukan oleh para pemimpin (James \& FigaroHenry, 2017). Aspek terbaik dari kepemimpinan adalah bahwa kita semua dapat belajar dan mengembangkan keterampilan kepemimpinan. Kita masingmasing memiliki beberapa kapasitas untuk kepemimpinan meskipun sebagian dari kita dilahirkan dengan sifat-sifat yang membuatnya lebih mudah untuk menjadi pemimpin, tetapi kita semua dapat mengembangkan keterampilan kepemimpinan. Di sisi yang lain pengetahuan, keterampilan, dan sikap terkait dengan kemampuan terlibat dalam kepemimpinan. Sebagian pemimpin tampaknya lebih kompeten dibidang lain dari pada apa yang mereka lakukan berkaitan dengan "jaminan kualitas dan akuntabilitas", "pembelajaran, dan pengajaran", "arahan strategis dan lingkungan kebijakan", dan komunikasi eksternal dan koneksi ke dunia luar (WingNg, 2010). Kapasitas kepemimpinan akan berupaya bersama dalam suatu organisasi untuk membangun kualitas pada "pegawai" yang berkontribusi pada kemampuan kepemimpinan mereka dengan manajemen kegiatan yang melibatkan perencanaan, pengendalian, pengarahan atau evaluasi pekerjaan orang lain.

Untuk itu kapasitas seorang pemimpin bukan bercerita tentang jabatan, pengaruh, penghargaan namun kepemimpinan adalah tentang "kapasitas" seseorang yang mampu dan terus mau belajar, dan berani menolak status quo. Selain itu kapasitas kepemimpinan dalam tim dikonseptualisasikan terutama dalam hal keterampilan, kemampuan, dan perilaku pemimpin individu atau atribut pemimpin lainnya seperti "karismatis" yang dianggap secara langsung memengaruhi proses dan kinerja tim. Membangun kapasitas kepemimpinan dengan objek yang berbeda pada umunya melibatkan model pengukuran yang mengambarkan keterampilan (hard, soft skill) dan perilaku yang diperlukan oleh setiap pemimpin (Northouse, 2013). Sebagai contoh studi yang dilakukan Echevarría, et al., (2013) menemukan bahwa kapasitas kepemimpinan dalam pengelolaan wilayah pesisir untuk memromosikan interaksi antara lembaga terkait dan pemangku kepentingan. Tujuannya adalah untuk meningkatkan pengetahuan pemangku kepentingan lokal tentang masalah zona pesisir dan implikasi pengelolaan zona pesisir terintegrasi adaptif untuk pengambilan keputusan yang tepat.

Lebih lanjut, para pemangku kepentingan memperoleh kapasitas untuk memromosikan interaksi antara kepentingan negara, pemerintah dan kelompok-kelompok masyarakat dan kearipan lokal mereka sendiri dalam kaitannya dengan pekerjaan pengelolaan wilayah pesisir, dapat menjadi dasar untuk perlindungan sumber daya alam dan untuk meningkatkan kualitas hidup penduduk pesisir. Sebab tata kelola adaptif melibatkan kepercayaan dan partisipasi penuh dari masyarakat setempat, namun kurang nya kejelasan kebijakan, kemauan politik, lemah nya koordinasi pemangku kepentingan, dikombinasikan dengan regenerasi tertentu budaya masyarakat pesisir, membuat pendekatan adaptif menjadi terorganisir dan mungkin sangat bermasalah. Untuk itu mengadadopsi tata kelola adaptif wilayah pesisir diperlukan pemahaman yang lebih kompleks, sebelum diadopsi dalam tataran praktis. Lebih lanjut desentralisasi dapat mengakibatkan tata kelola adaptif atau sebaliknya, asumsi ini didasari bahwa pemerintah daerah lebih sensitif terhadap pengaruh demokrasi dari 
pada pusat, akibat nya desentralisasi dapat menghalangi proses adaptasi jika kebijakan dianggap mewujudkan politik kepentingan.

\section{KESIMPULAN}

Tata kelola adaptif memberikan lensa yang menarik untuk memeriksa ekonomi politik dari respon kebijakan - mirip dengan konsep kegagalan pasar dalam ekonomi, tetapi diterapkan pada proses pembelajaran sosial dan pilihan kolektif yang lebih luas, termasuk pilihan kolektif tentang ruang lingkup dan struktur lembaga yang mengatur pilihan tingkat bawah oleh individu dan organisasi. Di masa depan sumber daya alam akan selalu berubah, karena itu manusia harus menanggapi dengan menyesuaikan diri dengan yang terus berubah. Ada dan akan selalu ada ketidakpastian dalam tata kelola ekosistem, baik sebagai manusia mengalami situasi baru, dan sistem ini berubah sebagai akibat dari tata kelola adaptif. Bahwa kebijakan harus memenuhi tujuan sosial, tetapi juga harus terus dimodifikasi dan fleksibilitas untuk adaptasi.

Kegagalan mungkin terjadi ketika ekosistem menunjukkan dinamika dan perilaku tak terduga. Tata kelola adaptif juga muncul sebagai akibat dari pergeseran nilai-nilai sosial, norma, atau mungkin kurangnya keragaman kelembagaan, dan menyediakan konteks untuk mengelola konsekuensi dari tata kelola sebelumnya untuk meningkatkan legitimasi dalam pelaksanaan tata kelola adaptif. Bagi pemerintah, dari beberapa kasus yang telah dibahasa sebelumnya tren untuk meningkatan keterlibatan masyarakat menjadi lebih besar. Karena tata kelola wilayah pesisir menyediakan pertumbuhan ekonomi baru bagi masyarakat lokal. Kearifan lokal berperan penting untuk menjadi stabilitas moderinasi yang dibawa dalam tata kelola adaptif itu sendiri. Akhirnya bagi peneliti masa depan topik tata kelola adaptif dapat digunakan untuk mengambarkan seberapa besar keterlibatan masyarakat-pemerintah-swasta untuk mencari jawaban dari berbagai isu yang komplek dalam tata kelola wilayah pesisir.

Dari pembahasan sebelumnya, inti sari artikel penelitian ini berupa rekomendasi adalah; 1). Tata kelola adaptif dapat dilaksanakan ketika berbagai kebijakan pendukung tersedia untuk melibatkan setiap komponen kepentingan; 2). Bagi pemerintah, kebijakan dapat dirumuskan melalui difusi kebijakan ketika terdapat keterbatasan pengetahuan tentang pengelolaan wilayah pesisir; 3). Bagi masyarakat, tata kelola adaptif akan meningkatkan partisipasi yang lebih besar dalam pengelolaan wilayah pesisir, serta mengali potensi sumber daya secara berkeadilan; 4). Bagi peneliti masa depan, artikel penelitian ini dapat menjadi sumber studi pendahuluan ketika mengkaji tata kelola adaptif wilayah pesisir secara empiris.

\section{DAFTAR PUSTAKA}

Abdullah, M., \& Koc, A. B. (2013). Oil removal from waste coffee grounds using two-phase solvent extraction enhanced with ultrasonication. Renewable Energy, 50, 965-970.

Ahlhorn, F. (2018). Integrated Coastal Zone Management: Status, Challenges and Prospects. Wiesbedwn: Springer Vieweg.

Al-Hamamre, Z., Foerster, S., Hartmann, F., Kröger, M., \& Kaltschmitt, M. (2012). Oil extracted from spent coffee grounds as a renewable source for fatty acid methyl ester manufacturing. Fuel, 96, 70-76.

Ambari, M. (2019, April 2019). Pentingnya Pengelolaan Zonasi Pesisir dan Pulau-pulau Kecil. Retrieved from Mongabay: https://www.mongabay.co.id/2019/ 04/16/pentingnya-pengelolaanzonasi-pesisir-dan-pulau-pulaukecil/

Andhika, L. R. (2017). Perbandingan Konsep Tata Kelola Pemerintah: 
Sound Governance, Dynamic Governance, dan Open Government. Jurnal Ekonomi dan Kebijakan Publik, 8(2), 87-102. doi:10.22212/jekp.v8i2.867

Assche, K. V., Beunen, R., \& Duineveld, M. (2014). Evolutionary Governance Theory: An Introduction. Heidelberg: Springer Science+Business Media .

Bevir, M. (2012). Governance: A Very Short Introduction. Oxford: Oxford University Press.

Bockstael, E. (2017). Critical Capacity Development: An Action Research Approach in Coastal Brazil. World Development, $\quad 94, \quad 336-345$. doi:10.1016/j.worlddev.2017.01.01 7

Bravo, J., Monente, C., Juániz, I., De Peña, M. P., \& C. C. (2013). Influence of extraction process on antioxidant capacity of spent coffee. Food Research International, 50, 610616.

Bryson, J. M., Quick, K. S., Slotterback, C. S., \& Crosby, B. C. (2012). Designing Public Participation Processes. Public Administration Review, 73(1), 23-34. doi:10.111/j.15406210.2012.02678.x

Caetano, N. S., Silva, V. F., \& Mata, T. M. (2012). Valorization of Coffee Grounds for Biodiesel Production. Chemical Engineering Transactions, 26, 267-272.

Carisano, A., \& Gariboldi, L. (1964). Gas chromatographic examination of the fatty acids of coffee oil. J. Sci. Fd Agric., 15, 619-622.

Chaffin, B. C., Gosnell, H., \& Cosens, B. A. (2014). A Decade of Adaptive Governance Ccholarship: Synthesis and Future Directions. Ecology and Society, 19(3), 1-13. doi:10.5751/ES-06824-190356
Couto, R. M., Fernandes, J., da Silva, M. G., \& Simões, P. C. (2009). Supercritical fluid extraction of lipids from spent coffee grounds. The Journal of Supercritical Fluids, 51(2), 159-166.

de Melo, M. M., Barbosa, H. M., Passos, C. P., \& Silva, C. M. (2014). Supercritical fluid extraction of spent coffee grounds: Measurement of extraction curves, oil characterization and economic analysis. The Journal of Supercritical Fluids, 86, 150-159.

Ernoul, L., \& Wardell-Johnson, A. (2013). Governance in Integrated Coastal Zone Management: a Social Networks Analysis of Cross-Scale Collaboration. Environmental Conservation, 40(3), 231-240. doi:10.1017/S0376892913000106

Fadli, Y., \& Nurlukman, A. D. (2018). Government Collaboration in Empowerment? A Collaborative Framework for the Government in Empowering Coastal Communities. Journal of Government \& Civil Society, 2(2), 145-161. doi:10.31000/jgcs.v2i2.1022

Fan, J., Wang, Q., Wang, Y., Chen, D., \& Zhou, K. (2018). Assessment of Coastal Development Policy Based on Simulating Sustainable LandUse Scenario for Liaoning Coastal Zone in China. Land Degradation \& Developement, 29(8), 2390-2402. doi:10.1002/ldr.3013

Finocchiaro, M. A. (2013). Meta Argumentation An Approach to Logic and Argumentation Theory. London: College Publications.

Gonzalez, A. G., Pablos, F., Martin, M. J., Leon-Camacho, M., \& Valdenebro, M. S. (2001). HPLC analysis of tocopherols and triglycerides in coffee and their use as 
authentication parameters . Food Chem., 73, 93-101.

Graycar, A. (2017). Corruption: Classification and Analysis. Policy and Society, 34(2), 87-96. doi:10.1016/j.polsoc.2015.04.001

Gui, M. M., Lee , K. T., \& Bhatia, S. (2008). Feasibility of edible oil vs. nonedible oil vs. waste edible oil as biodiesel feedstock. Energy, 33, 1646- 1653.

Gunderson, L. H., Cosens, B., \& Garmestani, A. S. (2016). Adaptive Governance of Riverine and Wetland Ecosystem Goods and Service. Journal of Environmental Management, 183(2), 353-360. doi:10.1016/j.jenvman.2016.05.024

Harahap, F. A. (2016). Penentuan siklus ekstraksi Soxhlet terbaik dan karakterisasi minyak kopi dalam pembuatan bahan baku biodiesel dari ampas kopi robusta. Bandar Lampung: Universitas Lampung.

Henocque, Y. (2013). Enhancing Social Capital for Sustainable Coastal Development: Is Satoumi the Answer? Estuarine Coastal and Shelf Science, 116, 66-73. doi:10.1016/j.ecss.2012.08.024

Hossain, M., Asadullah, M. N., \& Kambhampati, U. (2019). Empowerment and life Satisfaction: Evidence from Bangladesh. World Development, 122, 170-183. doi:10.1016/j.worlddev.2019.05.01 3

Huang, W.-L., \& Feeney, M. K. (2015). Citizen Participation in Local Government Decision Making: The Role of Manager Motivation. Review of Public Personnel Administration, 36(2), 188-209. doi:10.1177/0734371X15576410

International Coffee Organization. (2018, November 25). Trade Statistics Tables. Retrieved October 20, 2016, from

http://www.ico.org/total/production -table.pdf

James, F., \& Figaro-Henry, S. (2017). Building Collective Leadership Capacity Using Collaborative Twenty-First Century Digital Tools. School Leadership \& Management Formerly School Organisation, $37(5)$, 520-536. doi:10.1080/13632434.2017.13672 77

Kahaia, S. S., \& Lei, Y. (2019). Building Social Capital with Facebook: Type of Network, Availability of Other Media, and Social Self-Efficacy Matter. International Journal of Human-Computer Studies, 130, 113-129. doi:10.1016/j.ijhcs.2019.05.013

Karpouzoglou, T., Dewulf, A., \& Clark, J. (2016). Advancing Adaptive Governance of Social-Ecological Systems Through Theoretical Multiplicity. Environmental Science \& Policy, 57, 1-9. doi:10.1016/j.envsci.2015.11.011

Kingsly, M. (2015). Fraud and Corruption Practices in Public Sector: The Cameroon Experience. Research Journal of Finance and Accounting, 6(4), 1-8.

Kondamudi, N., Mohapatra, S. K., \& Misra, M. (2008). Spent Coffee Grounds as a Versatile Source of Green Energy. Journal of Agricultural and Food Chemistry, 56, 11757-11760.

Lang, T., \& Ramírez, R. (2017). Building New Social Capital With Scenario Planning. Technological Forecasting and Social Change, 124, 51-65. doi:10.1016/j.techfore.2017.06.011

Lee, R. G., \& Petts, J. (2013). Adaptive Governance for Responsible Innovation. In R. Owen, J. Bessant, \& M. Heintz, Responsible 
Innovation (pp. 143-164). Hoboken, NJ: John Wiley \& Sons.

Mergel, I. (2013). Social Media in the Public Sector: A Guide to Participation, Collaboration, and Transparency in the Networked World. San Francisco: John Wiley \& Sons.

Michels, A. (2012). Citizen Participation in Local Policy Making: Design and Democracy. International Journal of Public Administration, 33(4), 285-292.

doi:10.1080/01900692.2012.66130 1

Mussatto, S. I., Machado, E. M., Martins, S., \& Teixeira, J. A. (2011). Production, Composition, and Application of Coffee and Its Industrial Residues. Food Bioprocess Technol., 4, 661672.

Northouse, P. G. (2013). Leadership: Theory and Practice (6th ed.). Thousand Oaks, CA: SAGE Publications.

Nurhidayah, L. (2011). Integrated Coastal Zone Management in Indonesia: The Implementation and Its Challenges. Jurnal Masyarakat \& Budaya, 13(1), 67-96.

Oh, K., Hu, F. B., Manson, J. E., Stampfer, M. J., \& Willett, W. C. (2005). Dietary fat intake and risk of coronary heart disease in women: 20 years of follow-up of the Nurses' Health Study. American Journal of Epidemiology, 161, 672-679.

Ojwang, L., Rosendo, S., Celliers, L., Obura, D., Muiti, A., James, \& Mwangi, M. (2017). Assessment of Coastal Governance for Climate Change Adaptation in Kenya. Earth's Future, 5, 1119-1132. doi:10.1002/2017EF000595

Oliveira, M. G., Rozenfeld, H., Phaal, R., \& Probert, D. (2014). Decision Making at the Front End of
Innovation: The Hidden Influence of Knowledge and Decision Criteria. $R \& D$ Management, 45(2), 161-180. doi:10.1111/radm.12058

Peters, B. G. (2018). The Challenge of Policy Coordination. Policy Design and Practice, 1(1), 1-11. doi:10.1080/25741292.2018.14379 46

Poncian, J. (2019). When Government Commitment Meets Community Proactiveness: Governing Gas and Community Engagement in Tanzania. Energy Research \& Social Science, 52, 78-90. doi:10.1016/j.erss.2019.01.012

Predojevic, Z. J. (2008). The production of biodiesel from waste frying oils: A comparison of different purification steps. Fuel, 87, 3522-3528.

Ramalakshmi, K., Rao, J. M., TakanoIshikawa, Y., \& Goto, M. (2009). Bioactivities of low-grade green coffee and spent. Food Chemistry, $115,79-85$.

Schmidt, L., Prista, P., Suraiva, T., O'Riodan, T., \& Gomes, C. (2013). Adapting Governance for Coastal Change in Portugal. Land Use Policy, 31, 314-325. doi:10.1016/j.landusepol.2012.07.0 12

Sharma-Wallace, L., Velarde, S. J., \& Wreford, A. (2018). Adaptive Governance Good Practice: Show $\mathrm{Me}$ the Evidence! Journal of Environmental Management, 222, 174-184. doi:10.1016/j.jenvman.2018.05.067

Silva, M. A., Nebra, S. A., Machado Silva, M. J., \& \& Sanchez, C. G. (1998). The use of biomass residues in the Brazilian soluble coffee industry. Biomass and Bioenergy, 14, 457467.

Speer, K., \& Kölling-Speer, I. (2006). The lipid fraction of the coffee bean. 
Brazilian Journal of Plant Physiology, 18(1), 201-216.

Trein, P., Meyer, I., \& Maggetti, M. (2019). The Integration and Coordination of Public Policies: A Systematic Comparative Review. Journal of Comparative Policy Analysis: Research and Practice, 21(4), 332349.

doi:10.1080/13876988.2018.14966 67

Toci , A. T., Neto, V. J., Torres , A. G., \& Farah, A. (2013). Changes in triacylglycerols and free fatty acids composition during storage of roasted coffee. LWT - Food Science and Technology, 50, 581590.

Tsuzuki, W., Matsuoka, A., \& Ushida, K. (2010). Formation of trans fatty acids in edible oils during the frying and heating process. Food Chemistry, 123, 976-982.

Viani, R., \& Petracco, M. (2007). Coffee. In Ullmann's Encyclopedia of Industrial Chemistry (7th ed., pp. 467-498). Weinheim: Wiley-VCH.

Walker, S. D., \& Bonner, B. L. (2018). The Effects of Differing Knowledge Transfer Strategies on Group Decision Making and Performance. Behavioral Decision Making, 31(1), 115-126. doi:10.1002/bdm.2053

Walsh, C. (2019). Integration of Expertise or Collaborative Practice?: Coastal Management and Climate Adaptation at the Wadden Sea. Ocean \& Coastal Management, 167, 78-86.

doi:10.1016/j.ocecoaman.2018.10. 004

Warren, C. (2016). Leadership, Social Capital and Coastal Community Resource Governance: the Case of the Destructive Seaweed Harvest in West Bali. Human Ecology, 44,
329-339. doi:10.1007/s10745-0169832-y

Williams, A. P. (2016). The Development of Collaboration Theory: Typologies and Systems Approaches. In J. C. Morris, \& K. Miller-Stevens (Eds.), Advancing Collaboration Theory: Models, Typologies, and Evidence (pp. 1442). New York: Routledge.

WingNg, S. (2010). The Leadership Capacities of Aspiring Principals in Hong Kong. Procedia-Social and Behavior Science, 9, 1840-1844. doi:10.1016/j.sbspro.2010.1 
